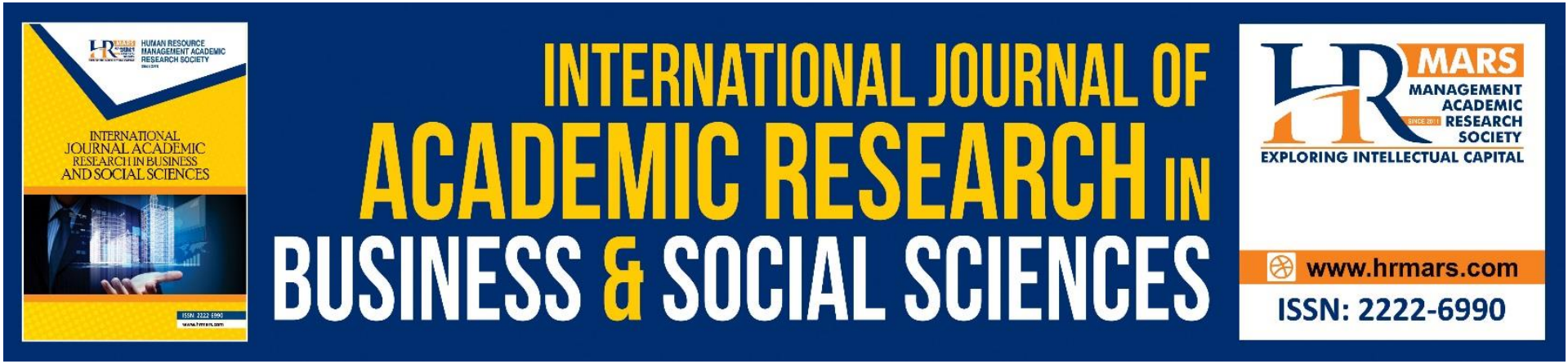

\title{
Characteristics of al-Muhtasib According to al-Ghazali (1111 AD) In Kitab Ihya' 'Ulum al-Din
}

Wan Hishamudin Wan Jusoh, Mohd Nizam Sahad, Mohd Hasrul Shuhari

To Link this Article: http://dx.doi.org/10.6007/IJARBSS/v11-i2/8658

DOI:10.6007/IJARBSS/v11-i2/8658

Received: 19 December 2020, Revised: 11 January 2021, Accepted: 21 January 2021

Published Online: 14 February 2021

In-Text Citation: (Jusoh et al., 2021)

To Cite this Article: Jusoh, W. H. W., Sahad, M. N., \& Shuhari, M. H. (2021). Characteristics of al-Muhtasib According to al-Ghazali (1111 AD) In Kitab Ihya' 'Ulum al-Din. International Journal of Academic Research in Business and Social Sciences, 11(2), 157-164.

\section{Copyright: @ 2021 The Author(s)}

Published by Human Resource Management Academic Research Society (www.hrmars.com)

This article is published under the Creative Commons Attribution (CC BY 4.0) license. Anyone may reproduce, distribute, translate and create derivative works of this article (for both commercial and non-commercial purposes), subject to full attribution to the original publication and authors. The full terms of this license may be seen at: http://creativecommons.org/licences/by/4.0/legalcode

Vol. 11, No. 2, 2021, Pg. 157 - 164

Full Terms \& Conditions of access and use can be found at http://hrmars.com/index.php/pages/detail/publication-ethics 


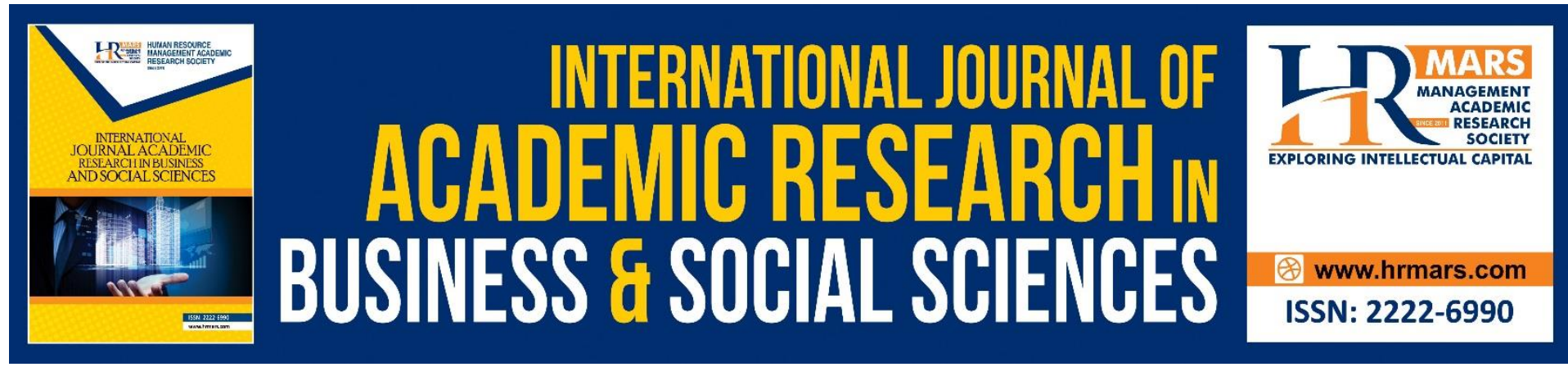

\title{
Characteristics of al-Muhtasib According to al- Ghazali (1111 AD) In Kitab Ihya' 'Ulum al-Din
}

\author{
Wan Hishamudin Wan Jusoh ${ }^{1}$, Mohd Nizam Sahad², Mohd \\ Hasrul Shuhari ${ }^{1}$ \\ ${ }^{1}$ Faculty of Islamic Contemporary Study Universiti Sultan Zainal Abidin Kuala Terengganu, \\ ${ }^{2}$ Malaysia School of Humanities Universiti Sains Malaysia Penang, Malaysia \\ Email: whishamudin@unisza.edu.my
}

\begin{abstract}
Al-Muhtasib played an important role in carrying out the responsibilities of al-Amr bi alMa'ruf wa al-Nahy 'an al-Munkar through a platform named as al-Hisbah. They are appointed by the government to monitor the running of the legal system and affairs that take place in society to be in line with Islamic teachings. History has proven their success in creating a society committed to the teachings of Islam from the upper class to the lower class. In fact, it is their responsibility to enforce the law with full integrity and dedication. Therefore, this article will discuss the characteristics of al-Muhtasib so that they can play a good and effective role. Document analysis method used to see in detail the relevant features written by alGhazali in Kitab al-Amr bi al-Ma'ruf wa al-Nahy 'an al-Munkar, one of the gist in Kitab Ihya' 'Ulum al-Din. The study to find the characteristics of al-Muhtasib as primarily a Muslim, mukallaf, capable, 'adalah, has been granted authorization from the government and knowledgeable. His views on this issue are almost identical to those of other Islamic scholars. Keywords: Al-Muhtasib, al-Ghazali, Ihya' 'Ulum al-Din
\end{abstract}

\section{Introduction}

Propagating the truth to other people and preventing them from falsehood is an important thing in Islam. The implementation of the task could create a society that lives in harmony and obey the commands of Allah SWT and stay away from all His prohibitions. The result of such obedience will bring various blessings and well-being in society. A thorough understanding and preparation is required to realize the task. This is because, without understanding and preparation, it will lead to failure and can even lead to greater disadvantages than the current corruptions that occurred. Therefore, the increase in understanding and preparation to perform the task of inviting people to the truth and preventing them from falsehood must be done diligently. The creation of man by Allah SWT has a very clear mission, which is to dedicate oneself to Him. All the rules and systems to achieve the level of true devotion have been explained by the Shari'ah which was conveyed to mankind through the messengers and apostles. In fact, Allah SWT appointed the messengers among the people so that they carry out the duties of al-Amr bi al-Ma'ruf wa alNahy 'an al-Munkar (AMNM). History proves that the first and second generations after 
Rasulullah SAW succeeded in building a consistent civilization in terms of the internal and external construction of humanity because they are committed in this matter. Thus, the opposite conclusion that can be made based on this statement is the neglection of AMNM will lead to the decline of the civilization of a society. This is because depravity is becoming more prevalent and good things will be seen as something unnecessary.

Therefore, the responsibility of AMNM should not be taken lightly as its role is so significant and influential to build a society that has an outstanding personality and acts as a constructor of material development with noble morals. Therefore, in the history of Islam, the institution introduced to carry out this task is officially named as hisbah which carries the meaning of a body appointed by the Islamic government that controls public affairs in maintaining the currency and protocols or etiquettes in the country (Mustafa et al., nd: 172). Whereas, according to Ibn Manzur, hisbah is taken from the word ihtasaba which means improvement in administration and supervision (Ibn-Manzur, 2003: 437). Meanwhile, it also means asking for the reward of goodness from Allah SWT and managing as well as paying attention in an issue (al-Azhari, 2001: 811). In fact, it also means reward (الأجر) and management (التدبير) (alJawhari, 2007: 232).

Al-Mawardi defined hisbah as the command to do good when ignorance is apparent and to prevent evil when it is clearly done by someone (al-Mawardi, n.d., p. 270). Apart from that, it is also defined as the power given to a person to carry out the responsibility of enjoining good and preventing evil with the truth from the Shari'ah and getting a credential from the government. Those who are entrusted can inflict punishment on those who disobey based on what has been prescribed by the Islamic law (Muhammad, 1996: 60). In fact, hisbah is also interpreted as an order to do good and prevent evil and improve human relationships (alShizari, 1981:6).

Therefore, the hisbah referred to here is the scheming in determining a person who commits an offense whether punished or otherwise. The purpose is to control the affairs of the life of the community in a country to comply with the system that has been set by Islamic law. To accomplish this purpose, the Islamic government will establish a body called al-Hisbah. It has a very close relationship with AMNM because the existence of the institution will enable the government to perform the task of inviting the community to the truth and prevent them from evil in a more systematic and effective manner which conducted by al-Muhtasib.

\section{Characteristics of al-Muhtasib}

In the discussion on al-muhtasib, as a whole, Islamic scholars have detailed the requirements that need to be acquired by them. Among the requirements meant are Islam, mukallaf, capable, 'adalah, has been granted authorization from the government and knowledgeable.

\section{Islam}

Those who are obliged to fulfil the responsibilities of AMNM must be a believer in Allah SWT (al-Bayanuni, 1999: 37). When a person embraces Islam, they are obliged to do the obligatory things and abandon the forbidden things. This requirement has no dispute among scholars because it is the main thing to determine a person is obliged to carry out religious instructions and abandon the prohibition. Therefore, they are obliged to implement AMNM because it is a religious obligation. In fact, it is an effort to uphold the truth and prevent evil and at the 
same time be able to develop society according to the Islamic way of life. Therefore, nonMuslims should not be involved in this same responsibility because they have different convictions and beliefs (Awdah, 1993: 497).

\section{Mukallaf}

The second requirement is mukallaf (Awdah, 1993: 497). This is because people who are not mukallaf are not obliged to order and forbid something. In fact, they are also not obliged to perform other duties as long as they do not meet the requirements of mukallaf such as adult, rational and understand Islamic law with the arrival of da'wah (al-Bayanuni, 1988:266). However, those who do not meet the requirements of mukallaf such as children, they should also perform this responsibility in accordance with their position and ability ('Awdah, 1993:496). This is because, calling for good and preventing evil is an important responsibility to see Islam practiced by all layers of society.

\section{Capable (al-Qudrah)}

A person who is obliged to carry out the responsibilities of AMNM must also be capable (alBayanuni, 1999: 40). What is meant by being capable here is that one is able to enjoin others to goodness and prevent from evil. If they are not able to do so, then they should be prevented from doing evil with their hearts by way of hatred and do not give in to the evil that is happening. Similarly, when a person is incapacitated from an external point of view, and it is feared that it will lead to the occurrence of a greater evil than the wrong that occurs, they are not obliged to carry out the AMNM order. In fact, they are not obliged to do so when it is known that the act of preventing evil does not produce any benefit.

Thus, a person who does not have al-Qudrah in performing the duties of AMNM, they are not obliged to perform it. This is because, Islam does not force a person to do what he is not able to do (al-Baqarah (2): 286). This Qur'anic verse explains that Allah SWT does not oblige a person to do something except when he has the ability to do it. Thus, the obligation of AMNM is not imposed on those who are incapable in the sense of not being able to invite someone to goodness and prevent from evil.

\section{'Adalah}

The next condition is 'adil (al-Bayanuni, 1999: 37), that is not a person who is wicked or commits a sin. This is because, people will find it difficult to accept what is called if the preacher is a depraved person which no good existed in him because he continuously commits sins. However, this condition is only a condition of perfection in implementing AMNM and not a mandatory condition because human beings are not free from sin (al-Bayanuni, 1999:39). Therefore, this opinion is held by most Islamic scholars, that is, the depraved people are also obliged to implement AMNM because there is no condition for its implementation free from sin. If it is required, then it will cause the implementation efforts of AMNM to be limited and it is possible that evil will further widespread ('Awdah, 1993: 499). However, there are a group of scholars who require that a person who implements AMNM should do and practice what he knows in religion and should not speak or tell what he does not do (al-Shizari, 1981: 6). In other words, they make the condition 'adalah a mandatory condition of a person implementing AMNM rather than a condition of perfection. They argue with the words of Allah SWT in Surah al-Baqarah (2): 44 which questions those who do not do good asking others to do it. 
Even so, if viewed from the point of view of the importance of the responsibility of AMNM itself, it is appropriate for every Muslim to play a role in instructing good and preventing evil. If the responsibility is limited to those who are 'adil, it is very likely that the people who will do good will decrease and those who do evil will increase. Furthermore, in the current context full of challenges and temptations toward immoral things, it is certainly difficult to escape from committing sin. Therefore, people who commit sins should also perform the duties of AMNM.

\section{Obtaining Authorization from The Government}

Next, one must obtain authorization from the government to carry out the responsibilities of AMNM (al-Shizari, 1981: 6). This is because the government is more aware of the criteria of people who are qualified to carry out this task. However, the election specifically by the government does not mean that the others do not have to carry out AMNM duties. This is because whoever sees evil, then he is obliged to prevent it ('Awdah, 1993: 500). The purpose of requiring authorization from the imam or ruler is to make its implementation more organized and systematic with the establishment of a body named as al-hisbah ('Awdah, 1993: 501). Therefore, the appointment from the government is only a condition of perfection because every Muslim must prevent evil as Rasulullah SAW said which means;

Whoever among you sees evil, let him change it with his hand. If he is unable to do so, then with his tongue. If he is unable to do so, then with his heart, and that is the weakest level of faith."

In the hadith above, Rasulullah SAW did not specialize in certain people to prohibit something wrong. In fact, the duty is not limited when every believer who sees evil must prevent it according to their ability, that is, either by hand, tongue or detestation with the heart.

\section{Knowledgeable}

A person who conducts AMNM should also have a clear knowledge and tasawur about good and evil according to Islamic assessment. One should not judge an evil and good according to the perspective of the mind simply by ignoring the guidance of the Qur'an and Hadith. This is because, when a person is ignorant about religion, it is possible that what is forbidden and commanded is something that is contrary to the will of Islam (al-Shizari, 1981: 6). With knowledge as well, it can lead a person to be pious, tawaduk, gentle and so on. In fact, with knowledge, one will be sensible and have a clear mind, especially in approaches to realize the responsibilities of AMNM (al-Maqdisi, 1996: 212).

Therefore, this condition has its own importance because it has to do with things that are makruf and munkar that will be asked to do and prevent it. However, for someone who does not have a deep knowledge of Islam, they should not let go of their hands to perform this duty. This is because, they can play a role in telling someone to things that are already known about their obligations, such as prayer, fasting and so on. Similarly, they need to prevent a person from doing illegal things that are already known to the public such as alcohol, adultery and so on. Based on the views that have been presented about al-Muhtasib, then the author also looks at the characteristics of al-Muhtasib according to the perspective of al-Ghazali. 


\section{Characteristics of al-Muhtasib according to al-Ghazali in Ihya' 'Ulum al-Din}

Kitab Ihya' 'Ulum al-Din by al-Ghazali is a well-known book among Muslims (Ibn-Khaallikan, n.d: 217). It is a reference material in libraries in the Islamic world, especially in the field of ethics (Massarat, 1992: 60) and Sufism. This does not mean that the book contains only those two fields, in fact it also contains a debate on the issue of faith, worship and muamalat. In other words, this book can be used as a basic reference to understand the teachings of Islam. In fact, this book also makes it easier for the reader because the topics in it are arranged systematically.

Al-Ghazali started writing this book after withdrawing from being a teacher at Madrasah Nizamiyyah, Baghdad. The purpose is to find happiness and peace in oneself through worship and getting closer to Allah SWT as well as isolating oneself from the busyness of the people. In a state of full awareness and tawaduk, al-Ghazali wrote this book which greatly affected his readers (al-Nadawi, 2002: 296). Al-Ghazali completed this writing in about 10 years (alShamali, 1979: 497) since his adventure left Baghdad in $488 \mathrm{AH}$. This means that the writing of this book is not short-lived. In fact, it is produced with full life experiences throughout his adventures. Thus, the opinion that says this book was completed between the years $492 \mathrm{AH}$ and $495 \mathrm{AH}$ contains validity as a result of this description that has been stated. Thus, alGhazali's efforts to complete his work should not be taken lightly and ignored. Moreover, the work produced is based on his knowledge, experience and observations as a critical thinker and desires to uphold the truth.

The arrangement of the titles in the book of Ihya' is divided into four main parts called rubu', namely Rubu'al-'Ibadat, Rubu'al-'Adat, Rubu'al-Muhlikat and Rubu'al-Munjiyat. The debate about al-muhtasib which is the focus of the author in this paper is in his writing, Ihya' 'Ulum al-Din under discussion related to al-Amr bi al-Ma'ruf wa al-Nahy 'an al-Munkar which is the ninth gist in Rubu 'al-'Adat. In this book, al-Ghazali categorizes debates into subheadings made in the form of chapters. Overall, the topics he touched on were the law of al-Amr bi alMa'ruf wa al-Nahy 'an al-Munkar, the pillars, the manners of al-muhtasib, the evils that often occur and the instructions as well as a prohibition on government.

However, the author focuses only on one aspect of al-Ghazali's thinking on this matter, which is the criteria that al-muhtasib should have. First, al-Ghazali put the obligatory condition of al-muhtasib, that is, they must be a mukallaf. This condition is a requirement for the school of al-Shafi'i (al-Ghazali adheres to this school) to determine a person is obliged to do what is commanded and leave what is forbidden. Secondly, al-muhtasib must be a believer who believes in Allah SWT. This means, as long as a person does not believe in Allah, they are not obliged to perform their responsibilities as al-muhtasib. Third, al-muhtasib should be one who has the nature of 'adalah. However, al-Ghazali put this condition only as a condition of perfection. He has a rather contradictory view with the opinion that says that this condition is a must have for al-muhtasib. In the Book of Ihya' 'Ulum al-Din, he presented the arguments brought by this group as the verses of the Qur'an in Surah al-Baqarah verse 44 and Surah alSaff verse 3. Meanwhile, al-Ghazali also disagreed with the opinion this is because according to him, the companions of Rasulullah SAW acted as al-muhtasib even though they were not free from sin. Furthermore, if the responsibility of AMNM is only obligatory on those who are pure from sin, then the implementation of the task will be neglected due to no human being who does not make mistakes (al-Ghazali, 2005: 376). Fourth, al-muhtasib should get 
authorization and appointment from the government to perform the duties of AMNM. However, al-Ghazali did not make it an absolute condition for al-muhtasib. In fact, he rejected the opinion that says these conditions need to be met. This is because there are many verses in the Qur'an and hadiths that ask anyone who sees evil, let them prevent it. In fact, they are considered sinful when they are silent when they see obvious wrongdoing (al-Ghazali, 2005:378). Thus, this condition only applies to al-muhtasib who is assigned to operate hisbah institutions in the Islamic government. This is to ensure that it runs more organized and systematic. Fifth, al-muhtasib must have the ability to carry out the responsibilities of AMNM. What al-Ghazali means by being capable is that a person should be able to prevent evil with his hands and use verbal methods to prevent it from happening (al-Ghazali, 2005:383). Meanwhile, for someone with a disability and mute, they should hate evil with their hearts.

In the meantime, al-Ghazali also puts the characteristics that al-muhtasib should have such as they should be knowledgeable, pious and have good morals (al-Ghazali, 2005: 400). From the point of view of knowledge, al-muhtasib should know the situation and circumstances of a matter related to AMNM to be implemented so as not to go beyond the limits set by religion. From the aspects related to the nature of warak, al-muhtasib should prevent himself from doing things that are against the religion that he already knows. This is because, sometimes someone who implements AMNM has a different purpose because there is no pious nature in them. If al-muhtasib does not have the nature of pious, it is likely that they will be played by others and will not be respected. Therefore, these two characteristics are necessary for almuhtasib in performing their duties. Nevertheless, the two characteristics mentioned are not sufficient without being accompanied by noble morals. According to al-Ghazali, with noble morals, one will perform AMNM with love and gentleness. The result of praiseworthy morals will also be able to make a person patient with all the trials that befall in their efforts to invite people to the truth and prevent them from falsehood.

\section{Conclusion}

In conclusion, al-Ghazali's thinking related to the characteristics of al-muhtasib which he outlined has many similarities with the opinions of other Islamic scholars. The aspects of similarity that are viewed are such as Islam, mukallaf and ability. However, there are some elements of difference related to the condition of obtaining authorization from the government and 'adalah. Al-Ghazali stated that al-muhtasib did not necessarily get authorization from the government to perform the duties of AMNM. The same goes for the condition 'adalah as what is outlined by the scholars. Al-Ghazali put this condition only as a condition of perfection that must exist in al-muhtasib. This means that a person who commits immorality and sins must also play a role in carrying out the responsibilities of AMNM.

Apart from that, al-Ghazali also thinks that al-muhtasib should be a person who is knowledgeable, has the nature of piety and noble morals. With knowledge, al-muhtasib will have a clear picture of his responsibilities. This is seen mainly in determining a wrongdoing to be prevented and preventive measures to be taken. In addition, the nature of warak can keep al-muhtasib from falling into things that can cause ridicule from society. Apart from that, almuhtasib also needs to have noble morals to evoke feelings of love and sincerity in their efforts to invite people to the truth and prevent from falsehood. 


\section{Acknowledgement}

This paper is founded on the research project of the Fundamental Research Grant Scheme FRGS/1/2019/SS06/UNISZA/02/03 (RR316). Pembinaan Model Amar Makruf Nahi Mungkar Dalam Amalan Kejiranan Penduduk Bandar di Malaysia. Special appreciation is owed to Ministry of Higher Education Malaysia (MOHE) and Universiti Sultan Zainal Abidin (UniSZA) for sponsoring and supporting this research.

\section{References}

Abdallah, A. A. M. (1996), Wilayah al-Hisbah fi al-Islam. Kaherah: Maktabah al-Zahra' Awdah, A. A. Q. (1993), al-Tashri' al-Jina'i al-Islami, v. 1. Beirut: Muassasah al-Risalah Al-Azhari, A. A. M. (2001), Mu'jam Tahdhib al-Lughah, v. 1, Beirut: Dar al-Ma'rif Al-Bayanuni, A. I. (1999), al-Amr bi al-Ma 'ruf wa al-Nahy 'an al-Munkar. Kaherah: Dar alSalam

Al-Ghazali, H. A. (2005), Ihya' 'Ulum al-Din (tahqiq by al-'Iraqi), v. 2. n.p.p.: Dar al-Bayan al'Arabi

Al-Jawhari, H. I. (2007), Mu'jam al-Sihah. Beirut: Dar al-Ma'rifah

Al-Maqdisi, A. M. (1996), al-Adab al-Shar'iyyah, v. 1. Beirut: Muassasah al-Risalah

Al-Mawardi, A. (n.d.), al-Ahkam al-Sultaniyyah wa al-Wilayat al-Diniyyah. n.p.p.: n.p.

Al-Nadawi, A. (2002), Rijal al-Fikr wa al-Da'wah fi al-Islam, v. 1. Damshiq: Dar al-Qalam

Sakirullah, A., Mohd, H. (2019). Civil Marriage In The Light Of Fiqh Al-Maqaasid, Nigeria As A Case Study. International Journal Of Academic Research In Business And Social Sciences, 9(4).

Mokhtar, W. K. A. W., Ibrahim, A., \& Embong, A. H. (2018). Al-'Aqīdat Al-Ṣaḥiḥat as the Essential Element of Worldview of Development Integrity and Accountability. International Journal Of Academic Research In Business And Social Sciences, 8(11), 328337.

Al-Nawawi, M. A. A. Z. Y. (1981), Sahih Muslim bi Sharh al-Nawawi, v. 2, Bab Bayan Kawn alNahy 'an al-Munkar min al-Iman wa Anna al-Iman Yazid wa Yanqus. n.p.p.: Dar al-Fikr

Al-Shamali, A. (1979) Dirasat fi Tarikh al-Falsafah al-Islamiyyah wa Athar Rijaliha. Beirut: Dar Sadir

Al-Shizari, N. A. A. (1981), Kitab Nihayah al-Ratbah fi Talab al-Hisbah. Beirut: Dar al-Thaqafah Ibn-Khallikan, S. A. A. (n.d.), Wafayat al-A'yan wa Anba' Abna' al-Zaman (tahqiq by Ihsan 'Abbas). Beirut: Dar al-Thaqafah

Ibn-Manzur. (2003), Lisan al-'Arab, v. 1. Kaherah: Dar al-Hadith

Mustafa, I. (n.d.). al-Mu'jam al-Wasit, v. 1. Istanbul: Caqri Yayinlari

Massarat, H. (1992), Aristotle And al-Ghazali. Delhi: Noor Publishing House 